\title{
$\square$
}

\section{The Fed's Monetary Policy Rule}

\author{
William Poole
}

This article was originally presented as a speech at the Cato Institute, Washington, D.C., October 14, 2005.

Federal Reserve Bank of St. Louis Review, January/February 2006, 88(1), pp. 1-11.

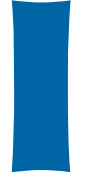

n 1936, Henry Simons published a paper, "Rules Versus Authorities in Monetary Policy," that not only became a classic but also is still highly relevant to today's policy debates. ${ }^{1}$ I rediscovered several important points in the paper while preparing this lecture.

In thinking about policy rules in recent years, I have tended to separate the political and economic cases for a rule. Simons argues for a much more integrated view of the issue:

There are, of course, many special responsibilities which may wisely be delegated to administrative authorities with substantial discretionary power...The expedient must be invoked sparingly, however, if democratic institutions are to be preserved; and it is utterly inappropriate in the monetary field. An enterprise cannot function effectively in the face of extreme uncertainty as to the action of monetary authorities or, for that matter, as to monetary legislation. $^{2}$

Thus, Simons argues that the rule of law that characterizes a democracy is also required to provide monetary policy predictability, which, in turn, is necessary for efficient operation of a market economy.

\footnotetext{
1 Simons (1936).

2 Simons (1936, pp. 1-2).
}

I've chosen a title designed to be provocative, for I suspect that few consider current Federal Reserve policy as characterized by a monetary rule. My logic is this: There is now a large body of evidence, which I'll review shortly, that Fed policy has been highly predictable over the past decade or so. If the market can predict the Fed's policy actions, then it must be the case that Fed policy follows a rule, or policy regularity, of some sort. My purpose is to explore the nature of that rule. Contrary to Simons's implication, the behavior of authorities can be predictable.

Before digging into specifics, consider what the "rules versus discretion" debate is about.

Advocates of discretion, as I interpret them, are primarily arguing against a formal policy rule, and certainly against a legislated rule. They believe that policy will be more effective if characterized by "discretion."

Discretion surely cannot mean that policy is haphazard, capricious, random, or unpredictable. Advocates of discretion agree with Simons that "many special responsibilities...may wisely be delegated to administrative authorities with substantial discretionary power." However, they do not agree with Simons that discretion "is utterly inappropriate in the monetary field."

Interestingly, Simons argued that a fixed money stock would be the best rule, but only if

William Poole is the president of the Federal Reserve Bank of St. Louis. The author appreciates comments provided by his colleagues at the Federal Reserve Bank of St. Louis. Robert H. Rasche, senior vice president and director of research provided special assistance. The views expressed are the author's and do not necessarily reflect official positions of the Federal Reserve System.

(C) 2006, The Federal Reserve Bank of St. Louis. Articles may be reprinted, reproduced, published, distributed, displayed, and transmitted in their entirety if copyright notice, author name(s), and full citation are included. Abstracts, synopses, and other derivative works may be made only with prior written permission of the Federal Reserve Bank of St. Louis. 
substantial institutional reforms were in place in financial markets, such as 100 percent reserve requirements against bank deposits. Given the institutional structure, Simons argued for a rule focused on price-level stabilization, because "no monetary system can function effectively or survive politically in the face of extreme alternations of hoarding and dishoarding." 3 That is, Simons believed that large variations in the velocity of money would make a fixed money stock rule work poorly.

Despite the nature of his argument for a pricelevel stabilization rule, elsewhere in the same paper Simons argued that, “[o]nce well established and generally accepted as the basis of anticipations, any one of many different rules (or sets of rules) would probably serve about as well as another." 4 I think his first argument was correctthat different rules, even once fully understood, would have different operating properties in the economy, and that a choice among various possible rules should depend on which rule yields better economic outcomes.

My view has evolved over time to this general position: Monetary economists have not yet developed a formal rule that is likely to have better operating properties than the Fed's current practice. It is highly desirable that policy practice be formalized to the maximum possible extent. Or, more precisely, monetary economists should embark on a program of continuous improvement and enhanced precision of the Fed's monetary rule. It is possible to say a lot about the systematic characteristics of current Fed practice, even though I do not know how to write down the current practice in an equation. It is in this sense that I'll be describing the Fed's policy rule. And given that, as far as I know, there is no other effort to state in one place the main characteristics of the Fed's policy rule; I'm sure that subsequent work will refine and correct the way I characterize the rule. Thus, I am redefining the "rule" to fit current practice, which has yielded an environment in which policy actions are highly, though not perfectly, predictable in the markets.

\footnotetext{
3 Simons (1936, p. 5).

4 Simons (1936, p. 29).
}

Before proceeding, I want to emphasize that the views I express here are mine and do not necessarily reflect official positions of the Federal Reserve System. I thank my colleagues at the Federal Reserve Bank of St. Louis for their comments-especially Bob Rasche, senior vice president and director of research.

\section{POLICY PREDICTABILITY- A SUMMARY OF FINDINGS}

I've discussed the predictability of Fed policy decisions on a number of occasions, most recently in a speech on October 4, 2005, entitled, "How Predictable Is Fed Policy?" Let me summarize the main findings.

Over the past decade, the Federal Open Market Committee (FOMC) has undertaken a number of steps toward greater transparency that have greatly improved the ability of markets to predict future policy actions. Among these steps are the announcement of policy actions at the conclusion of each FOMC meeting; the restriction of policy actions to regularly scheduled FOMC meetings, except under extraordinary conditions; the announcement of a specific numeric target for the federal funds rate in the post-FOMC meeting press releases and in the Directive to the Manager of the open market desk at the Federal Reserve Bank of New York; the inclusion of the individual votes at the FOMC meeting in the press release; and the expedited release of the minutes of the FOMC meetings. In addition, since 1989 all FOMC policy actions to change the target for the funds rate have been in multiples of 25 basis points. With the exception of one change of 75 basis points, all the changes have been either 25 or 50 basis points.

As I have noted previously, I believe that the evidence supports the conclusion that these steps toward increased transparency have brought the markets into much better "synch" with FOMC thinking about appropriate policy actions. My metric for judging how well markets have anticipated FOMC policy actions is the reaction of the yield on the 1-month-ahead federal funds futures contract between the close of business on the day 
before the FOMC meets and the close of business on the day of the meeting. Our research suggests that changes of less than 5 basis points are "noise." Larger changes reflect surprises to market expectations.

Since the middle of 1995, when the FOMC has undertaken policy actions at regularly scheduled meetings, the markets have been surprised only 12 times, as measured by a change of 5 basis points or more in the 1-month-ahead federal funds futures contract. Since the middle of 2003, when the FOMC introduced "forward looking" language into the press release, there have been no surprises. In contrast, on all four occasions when the FOMC instituted intermeeting policy actions, the markets were taken by surprise.

On the other side of the coin, FOMC decisions to leave the funds rate target unchanged have also become largely predictable. Since the middle of 1995 there have been only two occasions when the markets expected a change in the funds rate target and the FOMC left it unchanged.

These findings open this question: What are the circumstances under which market expectations of FOMC actions are adjusted, so that, by the time the FOMC meets, the outcomes are generally correctly foreseen? There is a substantial literature documenting interest rate responses to arriving information. Given that the federal funds futures market predicts FOMC policy decisions quite accurately, that literature provides insight into how the FOMC responds to new information. What I'll do now is to step back from that level of detail to discuss policy regularities at a high level, starting with policy goals.

\section{POLICY GOALS}

On many occasions, dating back to Paul Volcker's confirmation hearing in 1979, Fed officials have stated that the goal of low and stable inflation is there because it maximizes the economy's sustainable rate of economic growth. ${ }^{5}$

\footnotetext{
5 See, for example Committee on Banking Housing and Urban Affairs, United States Senate, Ninety-sixth Congress, first session, Hearings on the Nomination of Paul A. Volcker to be Chairman, Board of Governors of the Federal Reserve System, July 30, 1979, p. 20; Committee on Banking, Housing and Urban Affairs, United States
}

The dual mandate in the Federal Reserve Act, as amended, and in other legislation provides for goals of maximum purchasing power, usually interpreted as price stability, and maximum employment. There are two aspects to achieving the employment goal. First, achieving low and stable inflation maximizes the economy's growth potential and, probably, maximizes the sustainable level of employment. Second, the Fed can enhance employment stability through timely adjustments in its policy stance. A subsidiary goal of general financial stability is closely related to both inflation and employment goals.

The Fed has gravitated to a specification of the inflation goal stated in terms of the core personal consumption expenditures (PCE) index. At the FOMC meeting of December 21, 1999, Chairman Greenspan provided a clear statement of the case for focusing on the PCE price index rather than on the consumer price index (CPI).

The reason the PCE deflator is a better indicator in my view is that it incorporates a far more accurate estimate of the weight of housing in total consumer prices than the CPI. The latter is based upon a survey of consumer expenditures, which as we all know very dramatically underestimates the consumption of alcohol and tobacco, just to name a couple of its components. It also depends on people's recollections of what they spent, and we have much harder evidence of that in the retail sales data, which is where the PCE deflator comes from. ${ }^{6}$

There is evidence that the goal is effectively a 1 to 2 percent annual rate of change, averaged over a "reasonable" period whose precise definition depends on context. Evidence supporting

Senate, Ninety-eighth Congress, first session, The Renomination of Paul A. Volcker to be Chairman, Board of Governors of the Federal Reserve System for a term of 4 years ending August 6, 1987, July 14, 1983, p. 15; Committee on Banking, Housing and Urban Affairs, United States Senate, One Hundredth Congress, first session, The Nomination of Alan Greenspan of New York, to be a member of the Board of Governors of the Federal Reserve System for the unexpired term of 14 years from February 1, 1978, vice Paul A. Volcker, resigned; and, to be Chairman, Board of Governors of the Federal Reserve System for a term of 4 years, vice Paul A. Volcker, resigned, July 21, 1987, p. 29; Committee on Banking, Finance and Urban Affairs, United States House of Representatives, Testimony of Alan Greenspan, February 23, 1988, reprinted in the Federal Reserve Bulletin, April 1988, p. 227.

6 FOMC Transcript, December 21, 1999, p. 49. 
this view of the inflation goal appears in the minutes of the FOMC meetings of May 6, 2003, and August 9, 2005.7

I regard inflation stability as the primary goal not because it is more important in a welfare sense than maximum employment but because achieving low and stable inflation is prerequisite to achieving employment goals. Inflation stability also enhances, but does not guarantee, financial stability.

I take note, but will not further discuss here, the ongoing debate as to whether the inflation goal should be formalized as a particular numerical goal or range.

\section{CHARACTERISTICS OF THE FED POLICY RULE}

The Fed policy rule has a number of elements that can be identified and, in many cases, quantified. I'll now discuss the most important of these.

\section{The Taylor Rule}

Statements and testimony of Chairmen Volcker and Greenspan and other FOMC participants, supplemented by the transcripts and minutes of FOMC discussions over the past 25 years, clearly indicate that the long-run objective of Federal Reserve monetary policy is to maintain price stability, usually phrased as "low and stable inflation." In the short run, policy actions are undertaken with the intention of alleviating or moderating cyclical fluctuations, as Chairman Greenspan has noted:

[M]onetary policy does have a role to play over time in guiding aggregate demand into line with the economy's potential to produce. This may involve providing a counterweight to major, sustained cyclical tendencies in private spending, though we can not be overconfident in our ability to identify such tendencies and to determine exactly the appropriate policy response. ${ }^{8}$

\footnotetext{
7 FOMC Minutes, May 6, 2003, www.federalreserve.gov/fomc/ minutes/20030506.htm; FOMC Minutes, August 9, 2005, www.federalreserve.gov/fomc/minutes/20050809.htm.

8 Committee on Banking, Finance and Urban Affairs, United States
}

Over 10 years ago, John Taylor (1993) noted that these characteristics of FOMC policy actions could be summarized in a simple expression:

$$
\begin{aligned}
i & =p+.5\left(p-p^{*}\right)+.5 y+r^{*} \\
& =1.5\left(p-p^{*}\right)+.5 y+\left(r^{*}+p^{*}\right),
\end{aligned}
$$

where $i$ is the nominal federal funds rate, $p$ is the inflation rate, $p^{*}$ is the target inflation rate, $y$ is the percentage deviation of real gross domestic product (GDP) from a target, and $r^{*}$ is an estimate of the "equilibrium" real federal funds rate.

Under this characterization of the systematic or "rule like" character of FOMC policy actions, the funds rate is raised (lowered) when actual inflation exceeds (falls short of) the long-run inflation objective and is raised (lowered) when output exceeds (falls short of) a target level. In Taylor's example, the target for GDP was constructed from a 2.2 percent per annum trend of real GDP starting with the first quarter of 1984. In subsequent analyses this target has been interpreted as a measure of "potential GDP." When inflation and real GDP are on-target, then the policy setting of the real funds rate is the estimated equilibrium value of the real rate. This formulation of an interest rate monetary policy rule satisfies McCallum's properties for a rule that provides a "nominal anchor" to the economy. ${ }^{9}$ Taylor showed that his equation closely tracked the actual federal funds rate from 1987 through 1992 except around the stock market crash in October 1987.

For such a rule to be operational, data on the inflation rate and GDP must be known to the FOMC. In practice, the equation can be specified with lagged data on inflation and GDP. More generally the equation can be written as follows:

$$
i_{t}=\mathrm{a}\left(\bar{p}_{t-1}-p^{*}\right)+100 \mathrm{~b} \ln \left(y_{t-1} / y_{t-1}^{P}\right)+\left(r^{*}+p^{*}\right),
$$

where $\bar{p}_{t-1}$ is the previous quarter's PCE inflation rate measured on a year-over-year basis, $y_{t-1}$ is the log of the previous quarter's level of real GDP, and $y_{t-1}^{P}$ is the log of potential real GDP as estimated by the Congressional Budget Office. To

\footnotetext{
House of Representatives, testimony of Alan Greenspan, July 13, 1988. Reprinted in Federal Reserve Bulletin, September 1988, p. 611.

9 McCallum (1981).
} 


\section{Figure 1}

Greenspan Years: Funds Rate and Taylor Rules $\left(p^{*}=1.5, r^{*}=2.0\right) a=1.5, b=0.5$

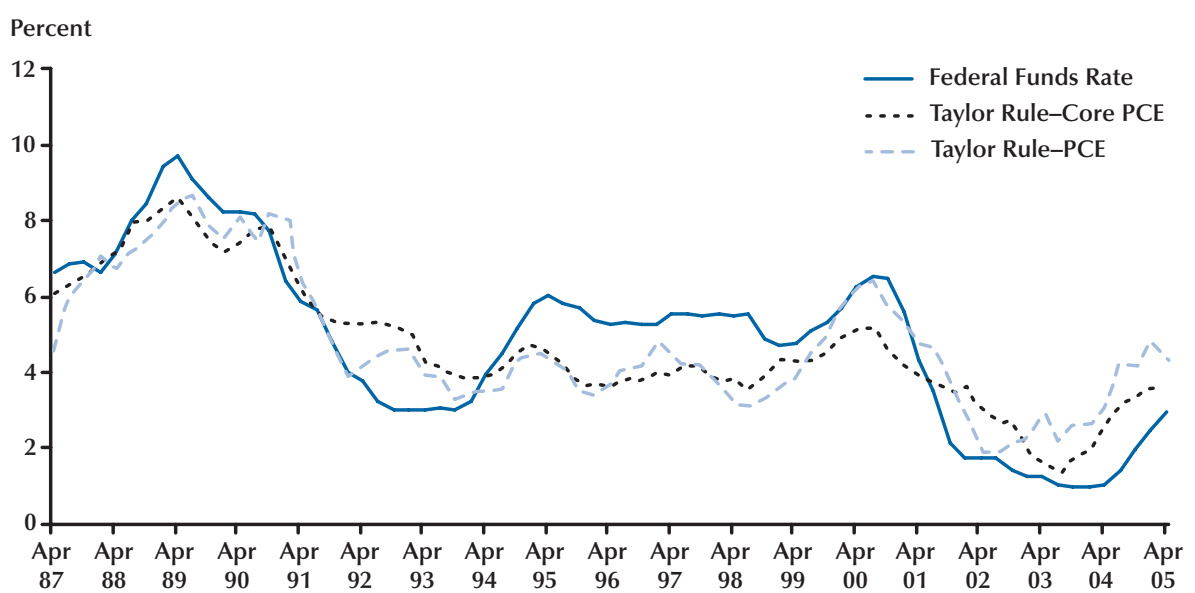

\section{Figure 2}

Greenspan Years: Funds Rate and Taylor Rules $\left(p^{*}=1.5, r^{*}=2.3\right) a=1.5, b=0.8$

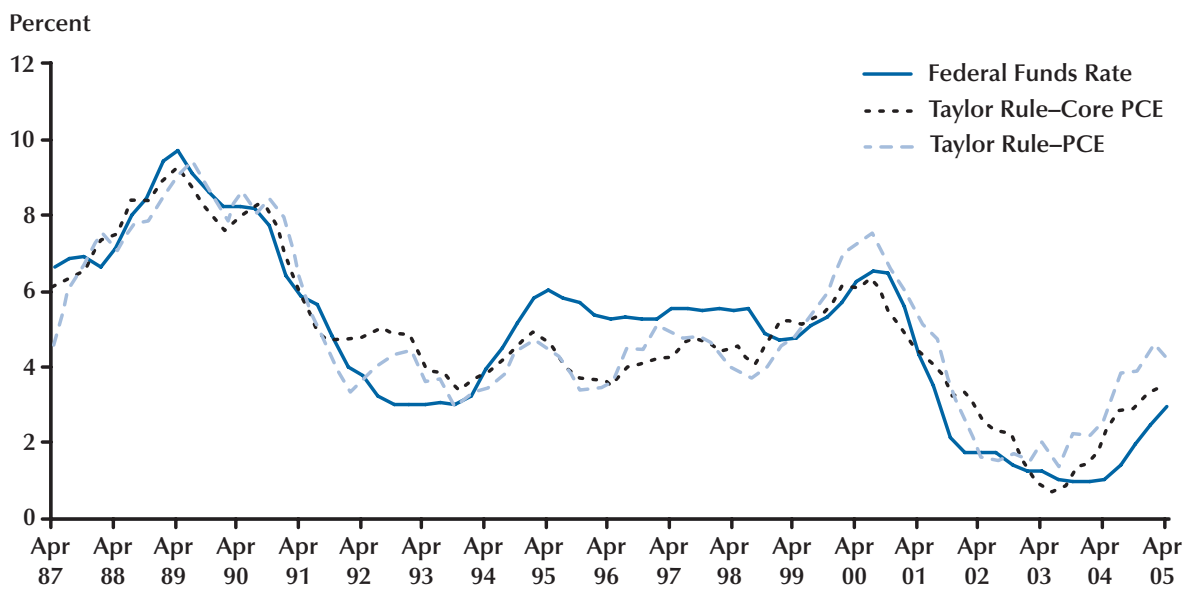


Figure 3

\section{Monthly Changes in Nonfarm Payroll Employment: January 1947-August 2005}

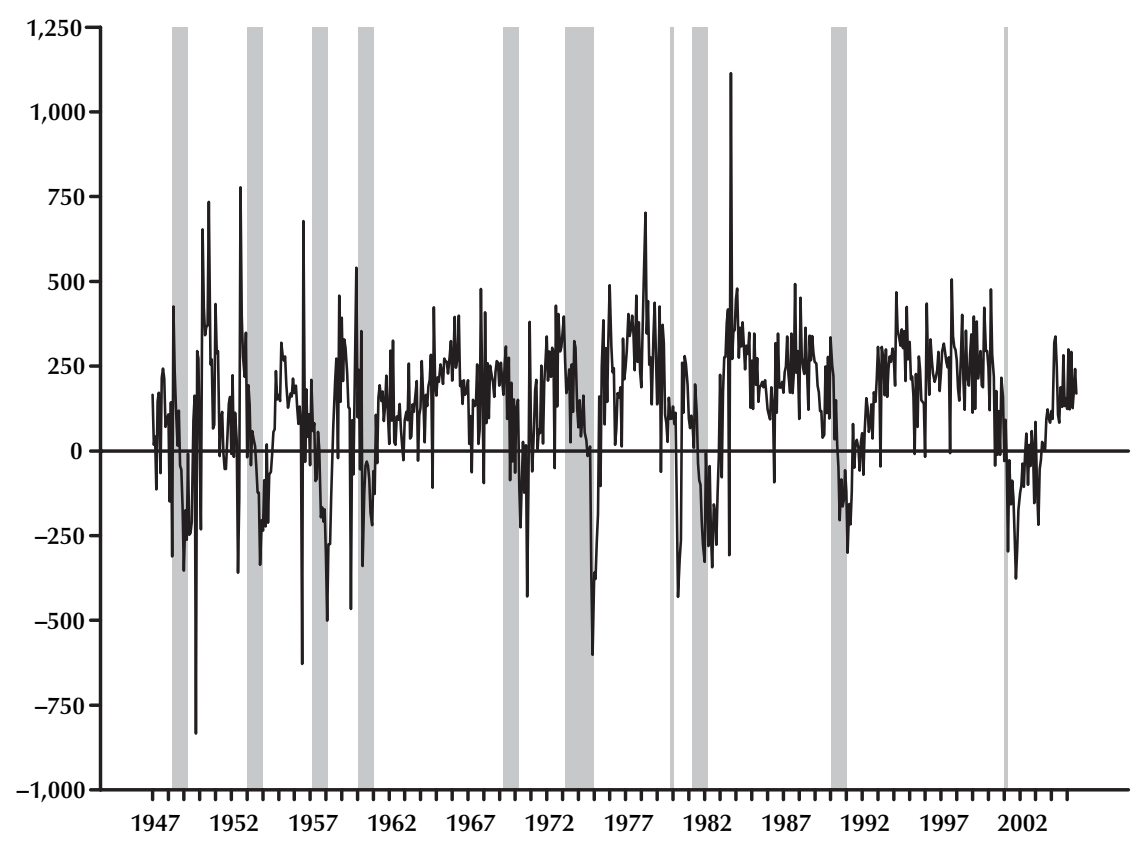

NOTE: Shaded bars indicate recessions.

ensure a "nominal anchor" for the economy, the coefficient a must be greater than 1.0.

Figure 1 shows the equation with the Taylor coefficients $(\mathrm{a}=1.5, \mathrm{~b}=0.5)$, an assumed equilibrium real rate of interest of 2.0 , and an assumed inflation target of 1.5 percent. The solid blue line shows the actual federal funds rate and the dashed lines the two Taylor rule funds rates. The smalldash black line is the rule constructed with the core PCE inflation rate; the long-dash light blue line with the PCE inflation rate. ${ }^{10}$ The average differences between the two "Taylor rules" and the actual funds rate over the entire period are 15 and 7 basis points, respectively. However, the volatility of each of the two Taylor rules is much less than that of the actual funds rate.

Figure 2 shows the comparison of the two Taylor rules with a larger coefficient on the output

10 Taylor originally specified his equation in terms of CPI inflation. Since the FOMC has stated a preference for PCE measures of inflation, those measures are used here. gap ( $b=0.8$ ) and a slightly higher assumed equilibrium real rate $\left(r^{*}=2.3\right)$. With these assumptions the average differences between the two equations and the funds rate over the entire period are 2 and -3 basis points, respectively, and the volatility of the two equations better approximates the volatility of the actual funds rate.

My purpose here is not to try to find the equation that reveals the policy rule of the Greenspan Fed; as I stated earlier, I do not know how to write down the current practice in an equation and the FOMC certainly does not view itself as implementing an equation. Rather, the illustrations should be viewed as evidence in support of the proposition that the general contours of FOMC policy actions are broadly predictable.

\section{Policy Asymmetry}

Under most circumstances the direction of FOMC policy actions is "biased" in a sense I'll explain. Policy bias exists because turning points 


\section{Figure 4}

\section{Autocorrelations of Monthly Payroll Employment Changes: January 1947-August 2005}

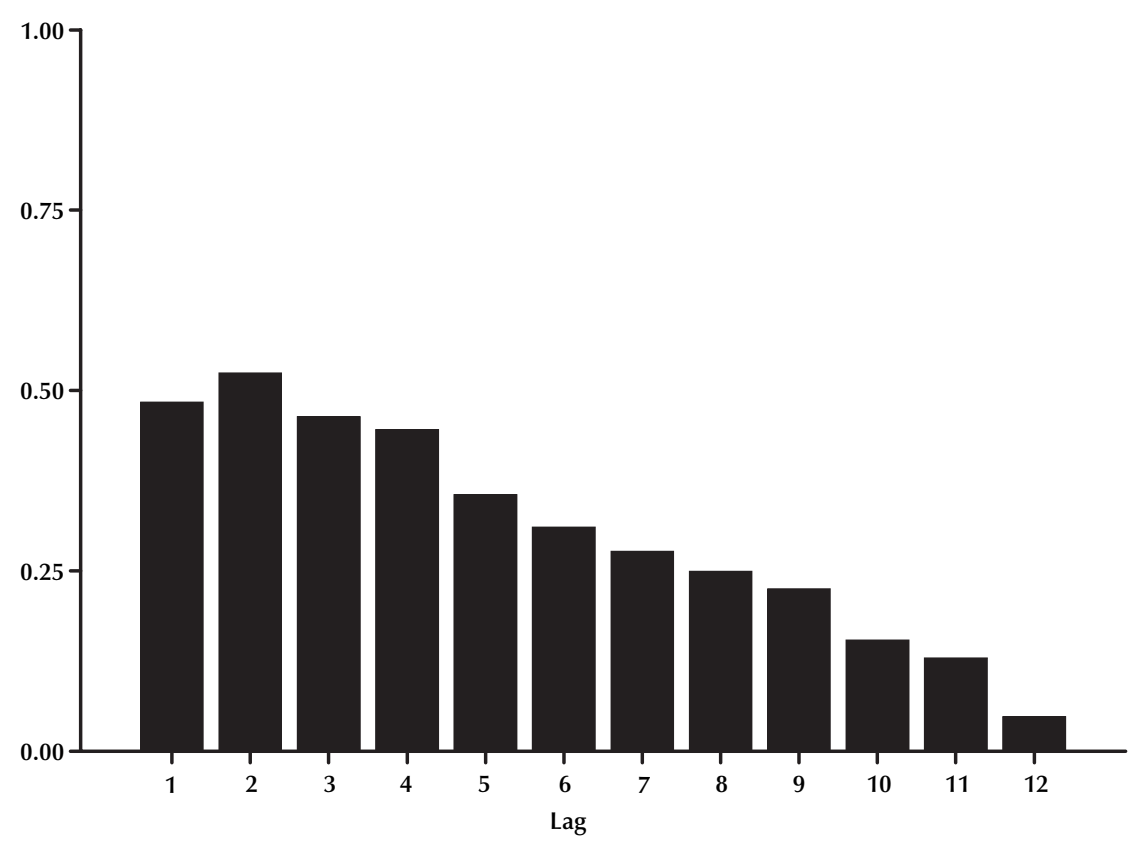

in economic activity-peaks and troughs of business cycles-are infrequent. Changes in economic activity as measured by output and employment are highly persistent. This persistence can be seen in Figure 3, which shows month-to-month changes in nonfarm payroll employment from January 1947 through August 2005. During expansions, employment changes are consistently positive; during recessions consistently negative. Changes opposite to the cyclical direction are rare and generally the consequence of identifiable transitory shocks such as those from strikes and weather disturbances. This pattern of business cycles generates strong autocorrelations in the month-tomonth changes in payroll employment, as shown in Figure $4 .^{11}$

Given such persistence, once it becomes apparent that a cyclic peak likely has occurred, the issue is never whether the Fed will raise the

${ }^{11}$ An estimate ARIMA model for monthly changes in nonfarm payroll employment over the period since 1947 indicates that

$\Delta$ Payroll_Emp $p_{t}-0.96 \Delta$ Payroll_Emp $p_{t-1}=\varepsilon_{t}-0.64 \varepsilon_{t-1}$. target funds rate but whether and how much the Fed will cut the target rate. Similarly, once it is apparent that an expansion is underway, the question is not whether the Fed will cut the target rate, but the extent and timing of increases.

\section{Data Anomalies}

Fed policy responds to incoming information, as it should. Sometimes data ought to be discounted because of anomalous behavior. For example, the FOMC has indicated that it monitors inflation developments as measured by the core rather than the total PCE inflation rate. This approach is appropriate because the impacts on inflation of food and energy prices are largely transitory; the difference between the inflation rate as measured by the total PCE index and as measured by the core PCE index fluctuates around zero.

Another example was the increase in tobacco prices in late 1998. Tobacco prices had a transitory impact on measured inflation, for both total and 
core indices, during December 1998 and January 1999, but produced no lasting effect on trend inflation. ${ }^{12}$ Similarly, information about real activity sometimes arrives that indicates transitory shocks to aggregate output and employment. An example of such a transitory shock is the strike against General Motors in June and July 1998. ${ }^{13}$ Similarly, the September 2005 employment report reflects the impact of Hurricane Katrina.

Transitory and anomalous shocks to the data are ordinarily rather easy to identify. Both Fed and market economists develop estimates of these aberrations in the data shortly after they occur. The principle of looking through aberrations is easy to state but probably impossible to formalize with any precision. We know these shocks when we see them, but could never construct a completely comprehensive list of such shocks ex ante.

Policymakers piece together a picture of the economy from a variety of data, including anecdotal observations. When the various observations fit together to provide a coherent picture, the Fed can adjust the intended rate with some confidence. The market generally understands this process, as it draws similar conclusions from the same data.

\section{Crisis Management}

The above rules are suspended when necessary to respond to a financial crisis. The major examples of the Greenspan era are the stock market crash of 1987, the combination of financial market events in late summer and early fall 1998 that culminated in the near failure of Long Term Capital Management, crisis avoidance coming up to the century date change at the end of 1999,

\footnotetext{
${ }^{12}$ From the December 1998 CPI release in January 1999: "Threefourths of the December rise in the index for all items less food and energy was accounted for by a 18.8 percent rise in the index for cigarettes, reflecting the pass-through to retail of the 45-cents-a-pack wholesale price increase announced by major tobacco companies in late November."

${ }^{13}$ From the July 16, 1998, Federal Reserve Statistical Release G.17 Industrial Production and Capacity Utilization press release: "Industrial production declined 0.6 percent in June after a revised gain of 0.3 percent in May. Ongoing strikes, which have curtailed the output of motor vehicles and parts, accounted for the decrease in industrial production." From the Employment Situation: July 1998, released August 7, 1998: "Nonfarm payroll employment edged up by 66,000 to 125.8 million, as growth was curtailed by strikes and plant shutdowns in automobile-related manufacturing."
}

and the 9/11 terrorist attacks. In each case, the nature of the response was tailored to circumstances unique to each event. In all cases, crisis responses were helpful because markets had confidence in the Federal Reserve, including confidence that extra provision of liquidity would be withdrawn before risking an inflation problem. In the absence of such confidence, the Fed's ability to respond would be severely curtailed.

The history of Fed crisis management since World War II is generally a happy one. Before the Greenspan era, significant events include the failure of Penn Central in 1970 and the near failure of Continental Illinois in 1984. Perhaps just as important, the Fed has not responded to certain events where it was called to do so. Examples would include the New York City financial crisis in 1975 and failure of Drexel Burnham Lambert in $1990 .{ }^{14}$

\section{Other Regularities in Policy Stance}

Since August 1989, the FOMC has adjusted the intended federal rate in multiples of 25 basis points only. After February 1994, when the FOMC first began to announce its policy decision at the conclusion of its meeting, with few exceptions all adjustments have been made at regularly scheduled meetings. These exceptions were April 18, 1994, September 29, 1998, January 3, 2001, April 18, 2001, and September 17, 2001.

In general, the Fed can use intermeeting adjustments to respond to special circumstances, such as the rate cut on September 17, 2001, in response to $9 / 11$, or to provide information to the market about a major change in policy thinking or direction, such as the rate cut on April 18, 2001. My own preference is to confine intermeeting adjustments to circumstances in which delaying action to the next meeting would have significant costs. In general, if the market believes that changed circumstances will lead to a changed decision at the next regularly scheduled meeting, then little is gained by acting between meetings.

\footnotetext{
${ }^{14}$ Drexel Burnham Lambert was first investigated by the Securities and Exchange Commission in late 1987 and charged with securities fraud in June 1988. A settlement was reached in December 1988, but the firm declared bankruptcy in February 1990.
} 
By reserving almost all actions to regularly scheduled meetings, intermeeting actions have special force, which can be valuable in meeting financial crises.

\section{ISSUES TO BE RESOLVED}

The rules-versus-discretion debate historically was framed in terms of policy actions. The focus on policy actions was natural because, historically, central bankers were reticent to comment on the rationale for their policy actions and only rarely provided hints about the future course of policy actions. Over the past 15 years, as central bankers, including the FOMC, have striven for greater transparency in monetary policy, communication in the form of policy statements has moved to center stage. It is clear that policy statements are just as important as policy actions, at least in the short run, because significant market effects can flow from these statements. We need to face a new question: Can policy statements become predictable? I think the answer in principle is largely in the affirmative, although evidence on the issue is scanty and I do not believe that policy statements are currently highly predictable.

Two significant elements in FOMC policy statements are the "balance of risks" assessment introduced in January 2000 and the "forward looking” language introduced in August 2003. The balance-of-risks assessment was introduced to replace the long-standing "bias" statement in the Directive to the Open Market Desk. Historically, the bias statement had referred to the intermeeting period and was not even made public in timely fashion until May 1999. With the regularization of FOMC policy actions on scheduled meeting dates, and issuance of a statement following every meeting starting with May 1999 to indicate whether or not the funds rate target was changed, a consensus emerged among FOMC participants that the bias formulation did not provide a clear public communication. The balance-of-risks statement attempted to provide insight into the major policy concerns of FOMC members over the "foreseeable future."

Initially, the Committee sought to summarize the risks for policy in the foreseeable future in a single assessment covering the prospects for both real economic activity and inflation. In June 2003, the assessment of the risk for sustainable growth was unbundled from the risk for inflation, allowing the Committee to express concerns in different directions about the two risks. Until April 2005, the balance-of-risks was an unconditional statement; since then, the assessment has been conditioned upon "appropriate monetary policy action."

Over the 49 FOMC meetings since February 2000, there have been 10 substantive changes in the wording of the balance-of-risks statement. ${ }^{15}$ One of these changes was a decision not to make a balance-of-risks assessment on March 18, 2003, in light of the uncertainty associated with the Iraq war. In the remaining 10 formulations of the statement, 5 assessed the risks as roughly balanced (or balanced conditional on appropriate policy), 3 indicated concern about economic weakness, 1 indicated concern about heightened inflation pressures, and 1 indicated a concern about the risk that inflation might become "undesirably low."

The switch in language on December 19, 2000, from a concern about heightened inflation pressures to economic weakness, was followed by a reduction in the federal funds target by 50 basis points at an unscheduled FOMC meeting on January 3, 2001. On August 13, 2002, the risk assessment was changed from balanced to weighted toward economic weakness, but the FOMC took no policy actions until it reduced the target for the funds rate by 50 basis points at its scheduled meeting on November 6, 2002-the second FOMC meeting after the change in language. The risk assessment was changed from balanced to weighted toward weakness at the May 6, 2003, scheduled FOMC meeting, and the federal funds rate target was reduced by 25 basis points at the subsequent FOMC meeting on June 25, 2003. Prior to August 2003, no policy actions were undertaken at a given FOMC meeting or its subsequent meeting when the risk assessment was balanced.

Beginning in August 2003, the FOMC added "forward looking" language to the press statement. Initially, the language indicated that "policy

\footnotetext{
15 These changes occurred on December 19, 2000; March 19, 2002; August 13, 2002; November 6, 2002; March 18, 2003; May 6, 2003; June 25, 2003; December 9, 2003; May 4, 2004; and March 22, 2005.
} 
accommodation can be maintained for a considerable period." In January 2004, the Committee changed the language to indicate that it could be "patient in removing its policy accommodation." The FOMC did not change the target federal funds rate while these statements were in effect. In May 2004, the Committee indicated that it "believes that policy accommodation can be removed at a pace that is likely to be measured." At its following meeting, the FOMC raised the federal funds rate target by 25 basis points. The Committee then raised the target rate by 25 basis points at all its subsequent meetings up to the time this speech was written. The most recent such meeting was September 20, 2005.

At a minimum, the FOMC can and should aspire to policy statements that are clear and do not themselves create uncertainty and ambiguity. The record since 2000 suggests that the balanceof-risks statement and more recently the forwardlooking language included in the press releases have provided consistent signals about the direction of future policy actions.

In interpreting the FOMC's policy statements, it is important that each statement be read against previous ones. Changes in the wording are critical to understanding the perspective of the FOMC members about future policy actions.

\section{RULE ENFORCEMENT}

Obviously, there exists no legal enforcement mechanism of the current rule. Nevertheless, there are certainly incentives for the Fed Chairman to follow the rule, or work to define improvements.

The most powerful incentives arise from market reactions to Fed policy actions. The federal funds futures market provides a sensitive measure of near-term market expectations and the eurodollar futures market a sensitive measure of longer-term funds rate expectations. The spread between conventional and indexed Treasury securities provides information on inflation expectations or, more accurately, inflation compensation. Options in these markets provide information on the diffusion of investor expectations. Volatility of market rates and accompanying market commentary provide quick feedback as to market reactions to Fed policy actions and policy statements. It is not in the Fed's interest to confuse or whipsaw markets, and for this reason market reactions provide an incentive for the Fed to conduct policy in a predictable fashion that at the same time achieves policy goals. Policy actions should be unpredictable only in response to events that are themselves unpredictable. The response function itself should be as predictable as possible. That is, given the arrival of new information, the goal is that the market should be able to predict the policy action in response to that information.

Although market responses are the most important disciplining force, FOMC members other than the Chairman also provide input, including input through dissents when a member feels strongly that a different policy decision would be better. Reserve Bank directors weigh in through discount rate decisions. Since 1994, except in unusual circumstances, the FOMC has not changed the intended federal funds rate unless several Reserve Banks have proposed corresponding discount rate changes. ${ }^{16}$

Finally, the general role of public discussion, including the highly visible congressional hearings, bears on the process. Skillful public officials do not want to be forced into a defensive posture when confronting questions in hearings and in Q\&A sessions following speeches. I'll leave it to political scientists to study the matter in detail, but will guess that public opinion plays a more important role than formal legal processes in enforcing many legislated and common law rules. If so, then public opinion can play an important role in enforcing extra-legal rules as well.

\section{A SUMMING UP}

Federal Reserve policy has become highly predictable in recent years; in the future this predictability will, I am sure, be seen as one of the

\footnotetext{
${ }^{16}$ During this period there were 7 occasions when the target funds rate was changed without an accompanying action by the Board of Governors to change the discount rate. Of the remaining 36 changes in the intended funds rate, 33 were accompanied by changes in the discount rate at four or more Federal Reserve Banks. On 24 of these occasions, the discount rate was changed at a majority of the Federal Reserve Banks.
} 
hallmarks of the Greenspan era. Little has been institutionalized, and for this reason the current Federal Reserve policy rule must be regarded as somewhat fragile. Still, future Chairmen will want to extend Alan Greenspan's successful era and therefore it will be in their interest to commit to pursue policy regularities that work well.

I do not claim to have accurately identified all aspects of the Fed's current policy rule. I am tempted to call it the "Greenspan policy rule," for Alan Greenspan has surely had far more to do with its construction than anyone else. Nevertheless, I believe that most elements of the rule have become part of a general Fed culture, understood at least roughly by other FOMC members and by staff. While it is appropriate to refer to the "Greenspan rule," I believe that FOMC debates and staff contributions have had a lot to do with development of the rule. For this reason, I believe that we should be hopeful that consistent and predictable Fed policy is likely to continue into the future.

\section{REFERENCES}

Simons, Henry C. "Rules Versus Authorities in Monetary Policy." Journal of Political Economy, February 1936, 44(1), pp. 1-30.

McCallum, Bennett T. "Price Level Indeterminacy with an Interest Rate Policy Rule and Rational Expectations." Journal of Monetary Economics, November 1981, 8(3), pp. 319-29.

Poole, William. "How Predictable Is Fed Policy?" University of Washington, Seattle Oct. 4, 2005; www.stlouisfed.org/news/speeches/2005/ 10_04_05.htm; Federal Reserve Bank of St. Louis Review, November/December 2005, 87(6), pp. 659-68.

Taylor, John B. "Discretion versus Policy Rules in Practice." Carnegie-Rochester Conference Series on Public Policy. Amsterdam: North-Holland, 1993, 39(0), pp. 195-214. 
